\title{
Analgesic effect of Sansevieria longiflora (Sim) water extract and xylocaine cream on surgical wound incision in rats
}

\author{
M. A. Kilani ${ }^{1 *}$, A. Z. Hassan ${ }^{1}$, S. T. Fadason $^{1}$, E. O. Abidoye ${ }^{1}$, L. O. Oladimeji ${ }^{1}$, A. M. Obalowu ${ }^{2}$ and H. M. \\ Badmus-Kilani ${ }^{3}$ \\ ${ }^{1}$ Department of Veterinary Surgery and Radiology, Ahmadu Bello University, P. M. B. 1096, Zaria, Kaduna State, Nigeria \\ ${ }^{2}$ University of Ilorin Veterinary Teaching Hospital, Ilorin, Kwara State, Nigeria \\ ${ }^{3}$ Ministry of Health, General Hospital Hunkuyi, Kaduna State, Nigeria
}

Received: 10 June 2019

Revised: 01 July 2019

Accepted: 01 July 2019

DOI: https://doi.org/10.3329/bjsir.v55i2.47630

\begin{abstract}
Analgesic effect of Sansevieria longiflora (S. longiflora) on surgically created wound was studied. Phytochemical screening of the crude water extracts was carried out following standard procedures. Sansevieria longiflora leaves was heated and the sap was squeezed into a sample bottle to be used as it was traditional believed. Its water extract was also prepared following standard procedure. Four (4) albino rats consisting of 2 males and 2 females were used for the study. One centimeter full thickness skin incision was created on 4 different locations at the dorsal region of each rat under anaesthesia. Each of the 4 wounds created was topically treated once daily with S. longiflora sap (E), S. longiflora water extract (F), Physiological saline solution (C) and xylocaine cream (G). The treatment regimen was rotated in a clockwise direction on each rat. Pain perception was evaluated with an algometer at 6:00 GMT (morning) and 18:00 GMT (evening) from day 1 post surgery for 5 days. The phytochemical studies revealed that $S$. longiflora contains carbohydrates, glycoside, saponins, steroids, triterpenes, flavonoids, alkaloids and tannins. Dayl after the surgery, the mean morning value of force $(\mathrm{N})$ required to elicit pain in xylocaine treated wounds $(5.2 \pm 0.79)$ were significantly higher $(\mathrm{p}<0.001)$ than that of physiological saline solution $(2.8 \pm 0.29)$ whereas, not different from that of $S$. longiflora sap $(4.48 \pm 0.57)$ and water extract $(4.2 \pm 0.6)$. Similarly, on the day 5 after the surgery, the mean morning value of force $(\mathrm{N})$ required to elicit pain in xylocaine treated wounds were significantly higher $(\mathrm{p}<0.0001)$ than that of physiological saline solution (PSS) treated wounds and not different from that of $S$. longiflora sap and water extract. This showed that $S$. longiflora sap and water extract possess analgesic effect on incisional wounds. This study serves as a preliminary study on this plant towards searching for potent analgesics that could be used for procedural pain management.
\end{abstract}

Keywords: Analgesic effect; Sansevieria longiflora; Algometer; Surgical wounds; Force gauge

\section{Introduction}

The medicinal properties of Sansevieria species is well documented (Wasciky and Hoehn, 1951; Mimaki et al., 1996). This includes treatment of different types of pain conditions including colic and ear aches (Aliero et al., 2008). The leaf sap could also be applied directly to infected wounds, cuts and grazes or used to treat fungal and scabies infection (Olivia, 2005). Traditionally, in treating ear aches and hemorrhoids, the leaves are heated and the warm juice is squeezed onto the affected area. In Nigeria, the leaves and roots of Sansevieria liberica are used in traditional medicine for the treatment of asthma, abdominal pains, colic, diarrhea, eczema, gonorrhea, hemorrhoids, hypertension, menorrhagia, piles, sexual weakness, snake bites and wounds of the foot (Osabohien and Egboh, 2008; Adeyemi et al., 2009). Similarly, ethanol and water extracts of Sansevieria trifasciata leaves has been reported to show a dose-dependent and significant increase in pain threshold under different pain tests (Anbu et al., 2009). 

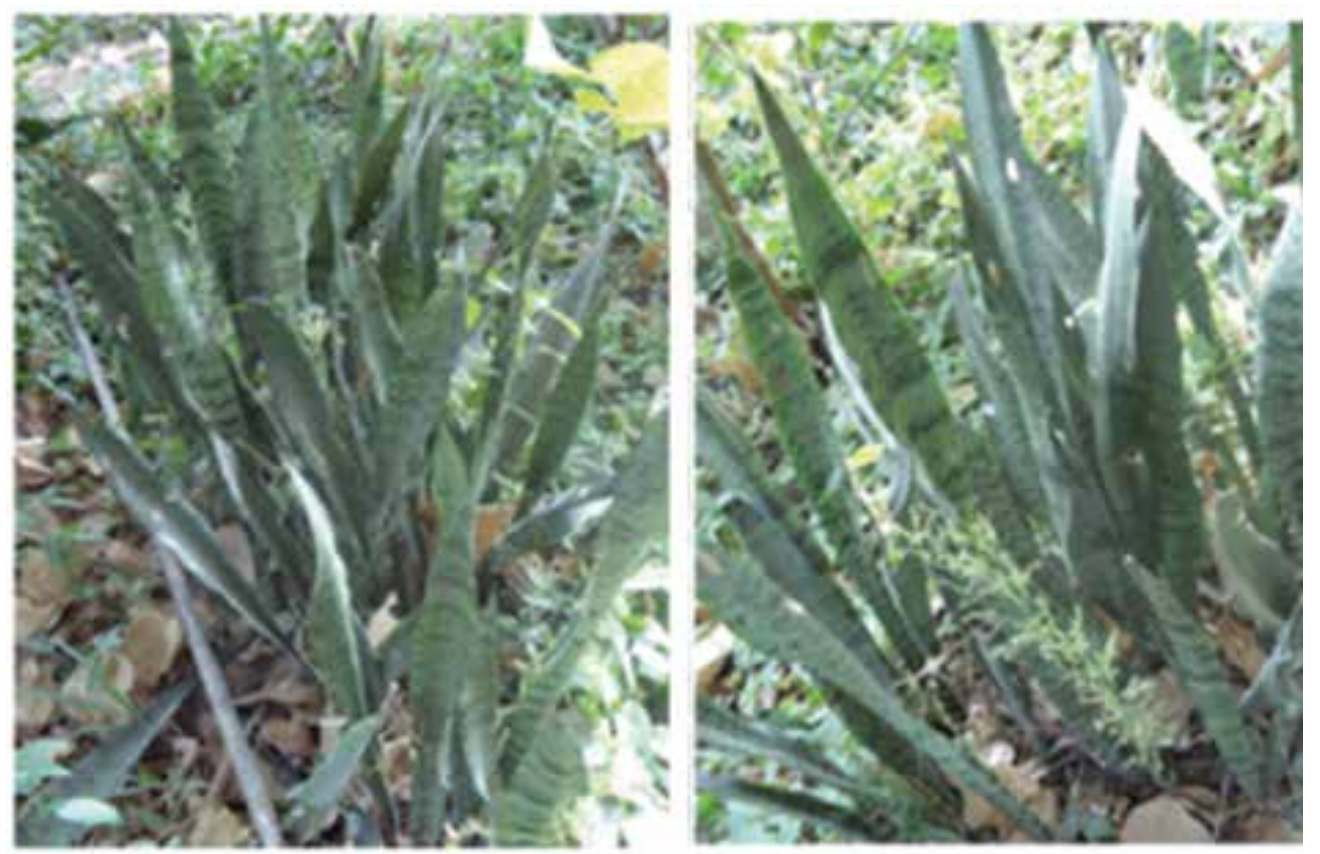

Fig. 1. Sansevieria longiflora (Sim)

Sansevieria longiflora (Figure 1) is commonly referred to as Florida bowstring hemp, mother-in-law tongue, bowstring hemp. It is also known in Nigeria as Oja ikooko (Yoruba) or Moda (Hausa). Though it is commonly used as ornamental plants in offices along with Sansevieria liberica in various parts of the country, it is as well known for its medicinal purposes. In the North-Eastern and South-Western part of Nigeria, the leaf of $S$. longiflora is popularly used as ligature. It is strapped round a very deep cut from the cutlass, sickles or other sharp objects while working on the farm. Subsequently, the leave is heated so as to be able to squeeze out the sap into the wounds. This is traditionally used to manage deep wounds and chronic wounds that failed to heal. The root decoction is also used to treat whooping cough and diabetes in human.

Self-reporting system facilitates pain treatment in most human patients (Rocca et al., 2015) unlike in animals. The research into pain assessment in animals is ongoing. Pain perception has been assessed by several authors in animals using different methods including analysis of physiological variables (heart rate, respiratory rate), measurement of hormones (cortisol, adrenaline) (Bufalari et al., 2007), subjective pain scales (visual analogue scores, numerical rating scales) (Mathews et al., 2014), analysis of electrophysiological parameters (electroencephalograms, evoked potentials), behaviour of the animal (Molony and Kent, 1997) and digital pressure palpation. Quantitative pain assessment could be done using equipments like digital force gauge algometer, anaesthesiometer and WAGNER
Pain Test ${ }^{\mathrm{TM}}$ Algometer. Pressure algometry has been proven to be a valid measure of localized pain in muscle, joints, tendons, ligaments and bones (Franco et al., 2014; Manufacturer's guide). Hence, Pain Test ${ }^{\mathrm{TM}}$ Algometer produced by WAGNER were used to test for pain threshold, tolerance and monitor the treatment progress by pressure algometry at different point of incision.

Stimulation of the peripheral neural receptors due to noxious stimuli like surgical incision leads to nociceptive pain (Woolf, 2010; Mark et al., 2015). This leads to inflammatory pain which results gradually from the activation of the immune system in response to injury (Woolf, 2010; Mark et al., 2015). Pain management is a key to success in medical practise (Mark et al., 2015). Different modalities in managing pain are being discovered (Mathews et al., 2014). However, several adverse effects are associated with the use of drugs. Respiratory depression, decreased gastrointestinal motility, increased appetite, sedation, euphoria and nausea are associated with administration of opioids (Coetzee, 2011) while gastric ulceration (Lascelles et al., 2005), nephrotoxicity (Crandell et al., 2004) and delayed bone healing (Ochi et al., 2011) has been reported with Non-Steroidal anti-inflammatory drugs (NSAIDs). Hence, there is need for continual search of alternative agent that is more potent with little or no side effects. More so, phytotherapeautical agents are relatively cheaper and without fear of drug residue in the meat product (Dhama et al., 2015), hence this research becomes important. Since, Sansevieria longiflora is readily available and 
commonly used by traditional people in Nigeria to manage ailments related to pain, it is therefore, necessary to investigate the notion behind its usage.

\section{Materials and methods}

\section{Collection and identification of the plant samples}

The leaves of the $S$. longiflora was collected from Obokun Local Government Area of Osun state Nigeria and was confirmed in the Herbarium of the Botanical Garden of Ahmadu Bello University, Zaria, with voucher specimen number of 1821 .

\section{Preparation of crude extract}

Sansevieria longiflora leaves was heated and the sap (E) was squeezed into a sample bottle to be used as it was traditional believed. To prepare the crude water extract of $S$. longiflora (F), the leaves were air dried and the dried powder of the plant was extracted and stored at $4^{\circ} \mathrm{C}$ in air tight bottles as described by Prashanthi et al. (2012).

\section{Phytochemical analysis}

The phytochemical screening of the crude extracts was carried out as described by Evans and Trease (1996), Harborne (1973) and Sofowara (1993) so as to evaluate for the presence of secondary metabolites such as saponins, alkaloids, flavonoids, steroids, tannins, cardiac glycosides, glycosides, and proteins.

\section{Experimental protocol}

Incisional wound model was adopted. Four albino rats consisting of 2 males and 2 females of 24 weeks old weighing about $200 \pm 20 \mathrm{~g}$ were used. They were housed separately in a steel cage and fed with commercial rat feed (prepared from Vital Feed ${ }^{\circledR}$ grower mash) and water ad libitum. The research was conducted based on the ethical guideline and rules by the Ahmadu Bello University Committee on Animal Use and Care. The approval number given was ABUCAUC/2016/027. The animals were allowed to acclimatize for 2 weeks before the experiment. Each rat was anesthetized by intra muscular injection of Rompun $^{(\mathrm{R})}$ (xylazine hydrochloride) and ketamine hydrochloride at the dosage of $5 \mathrm{mg} / \mathrm{kg}$ and 40 $\mathrm{mg} / \mathrm{kg}$ respectively. One centimeter full thickness skin incision was created on 4 different locations at the dorsal region of each rat under anaesthesia. Each of the 4 wounds created (E, F, C, and G) was topically treated once daily with S. longiflora sap, S. longiflora aqueous extract, Physiological saline solution (PSS) and Xylocaine cream respectively. The xylocaine cream consists of Lidocaine hydrochloride Gel B.P which was produced by Alves Healthcare Pvt. Ltd. Nangal Uperia, Swarghat Road, Road, India (Mfg. Lic No. HP/DRUGS/MB/07/676). The treatment regimen was rotated in a clockwise direction on each rat.

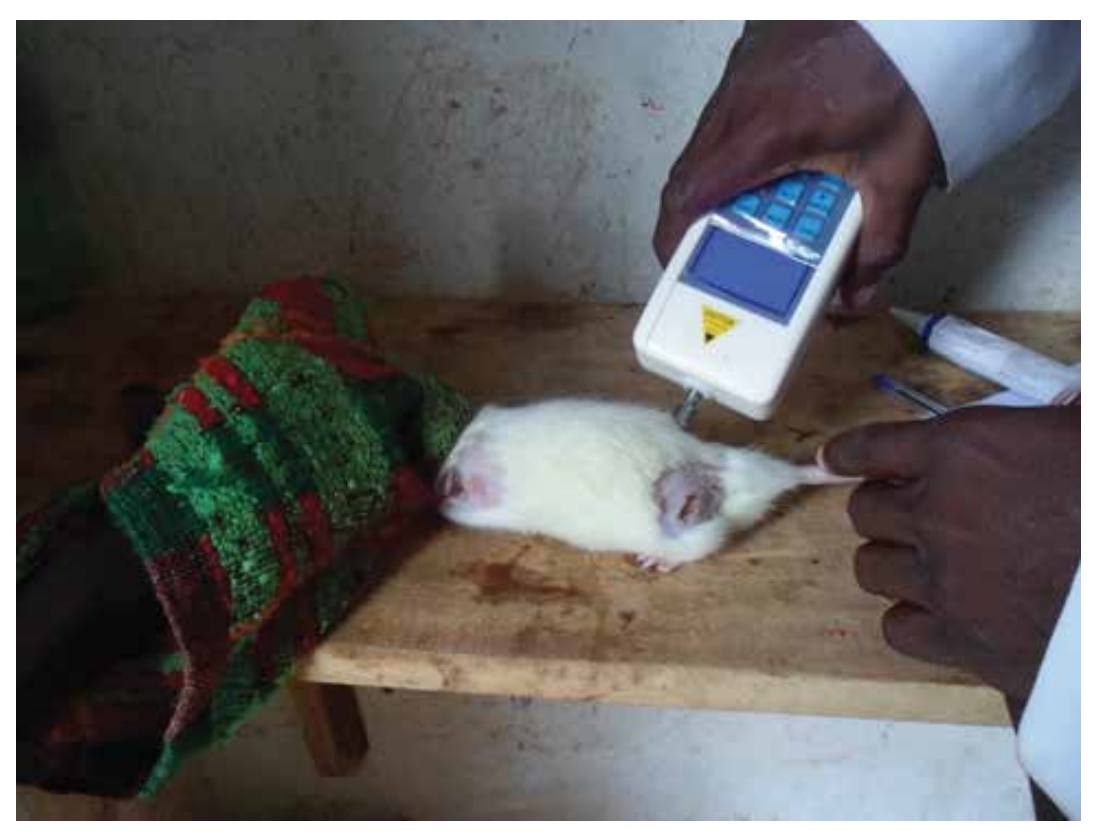

Fig. 2. Evaluation of pain perception in rats using an algometer 


\section{Postoperative pain evaluation}

Pain perception was evaluated with an Algometer (digital force gauge machine: HF-200 produced by Orchid Scientific, B-59 MIDC, Ambad Nashik-422010 and product ID: ALGO.D.1/16.17/01) after 15 minutes of treatment at 12 hours intervals from day 1 post surgery for 5 days (Figure 2).

Data analysis

All data were expressed as means \pm SEM (standard error of mean). Two ways ANOVA were used to analyze the data recorded. Bon ferroni post-hoc test was used for multiple comparisons. Statistical analyses were performed using the Graphpad prism 5.0 for sciences. P-Values of less than 0.05 were considered as statistically significant

\section{Results and discussion}

\section{Phytochemical studies}

The preliminary phytochemical studies (qualitative analysis) on the leaves of $S$. longiflora reveals that it contains carbohydrates, glycoside, saponins, steroids, triterpenes, flavonoids, alkaloids and tannins (Table I). Though there is limited information on the phytoconstituents of $S$. longiflora however, similar studies have revealed the presence of carbohydrates, glycoside, saponins, steroids, triterpenes, flavonoids and tannins in Sansevieria roxburghiana (Nweze et al., 2004; Philip et al., 2011; Pramoda and Hanumanth, 2015), Sansevieria trifasciata and Sansevieria liberica (Ogukwe et al., 2004; Sunilson et al., 2009). More so, Sansevieria roxburghiana was reported to contain quinone, proteins, anthocyanin and betacyanin (Nweze et al., 2004; Philip et al., 2011; Pramoda and Hanumanth, 2015).

Analgesic properties

The mean values of the force $(\mathrm{N})$ required to eliciting pain increased with days in all the treated groups with slight variation as presented in the Figure 3 and 4. Generally the normal saline group tolerated less force (more pain) while the Xylocaine treated group tolerated more force (less pain). On the morning of day 1 after the surgery, the force $(\mathrm{N})$ required in eliciting pain in $S$. longiflora sap, S. longiflora water extract, PSS and xylocaine cream were $4.48 \pm 0.57,4.2 \pm 0.60,2.8 \pm$ 0.29 , and $5.2 \pm 0.79$ respectively (Figure 3 ). While the force recorded in evening were $3.53 \pm 0.86,3.23 \pm 0.36,2.58 \pm$ 0.33 and $5.40 \pm 0.66$ respectively (Figure 4). On the morning of day 5 after the surgery, the force $(\mathrm{N})$ required to eliciting pain in S. longiflora sap, S. longiflora water extract, PSS and xylocaine cream were $9.83 \pm 2.20,6.93 \pm 0.67,5.93 \pm 0.92$ and $12.63 \pm 3.78$ respectively (Figure 3 ). While the force recorded in evening were $8.53 \pm 1.19,6.93 \pm 1.22,6.18 \pm$ 0.90 , and $9.95 \pm 1.96$ respectively (Figure 4).

On the morning of day 1 after the surgery, the maximum force required to elicit pain with xylocaine treated wound $(5.2 \pm$ $0.79)$ was significantly higher $(p<0.001)$ than that of PSS treated wounds $(2.8 \pm 0.29)$ whereas, not different from the force required by the $S$. longiflora sap $(4.48 \pm 0.57)$ and water extract $(4.2 \pm 0.6)$. While in the evening the force tolerated by the xylocaine cream treated wounds $(5.4 \pm 0.66)$ was significantly higher $(p<0.001)$ than that of PSS treated wounds

Table I. Phytochemical constituents of sansevieria longiflora

\begin{tabular}{|c|c|c|}
\hline $\mathrm{S} / \mathrm{N}$ & Chemical Test & Sansevieria longiflora \\
\hline \multirow[t]{3}{*}{1} & Carbohydrates & \\
\hline & Molisch's test & + \\
\hline & Fehling's test & - \\
\hline \multirow[t]{3}{*}{2} & Cardiac glycoside & \\
\hline & Kella-killiani test & + \\
\hline & Kedde's test & + \\
\hline \multirow[t]{2}{*}{3} & Free Anthraquinones & \\
\hline & Borntrager's test & - \\
\hline \multirow[t]{2}{*}{4} & Combined Anthracene & \\
\hline & Modified Borntrager's test & - \\
\hline \multirow[t]{3}{*}{5} & Saponins & \\
\hline & Frothing test & + \\
\hline & Hemolysis test & + \\
\hline \multirow[t]{2}{*}{6} & Steroids and Triterpenes & \\
\hline & Leiberman-Burchards test & + \\
\hline \multirow[t]{3}{*}{7} & Flavonoids & \\
\hline & Shinoda test & + \\
\hline & Sodium hydroxide test & + \\
\hline \multirow[t]{3}{*}{8} & Tannins & \\
\hline & Lead sub-acetate test & + \\
\hline & Ferric chloride test & - \\
\hline \multirow[t]{3}{*}{9.} & Alkaloids & \\
\hline & Mayer's test & + \\
\hline & Dragendorff's test & + \\
\hline \multirow[t]{2}{*}{ Key: } & $+:$ Present & \\
\hline & - : Absent & \\
\hline
\end{tabular}




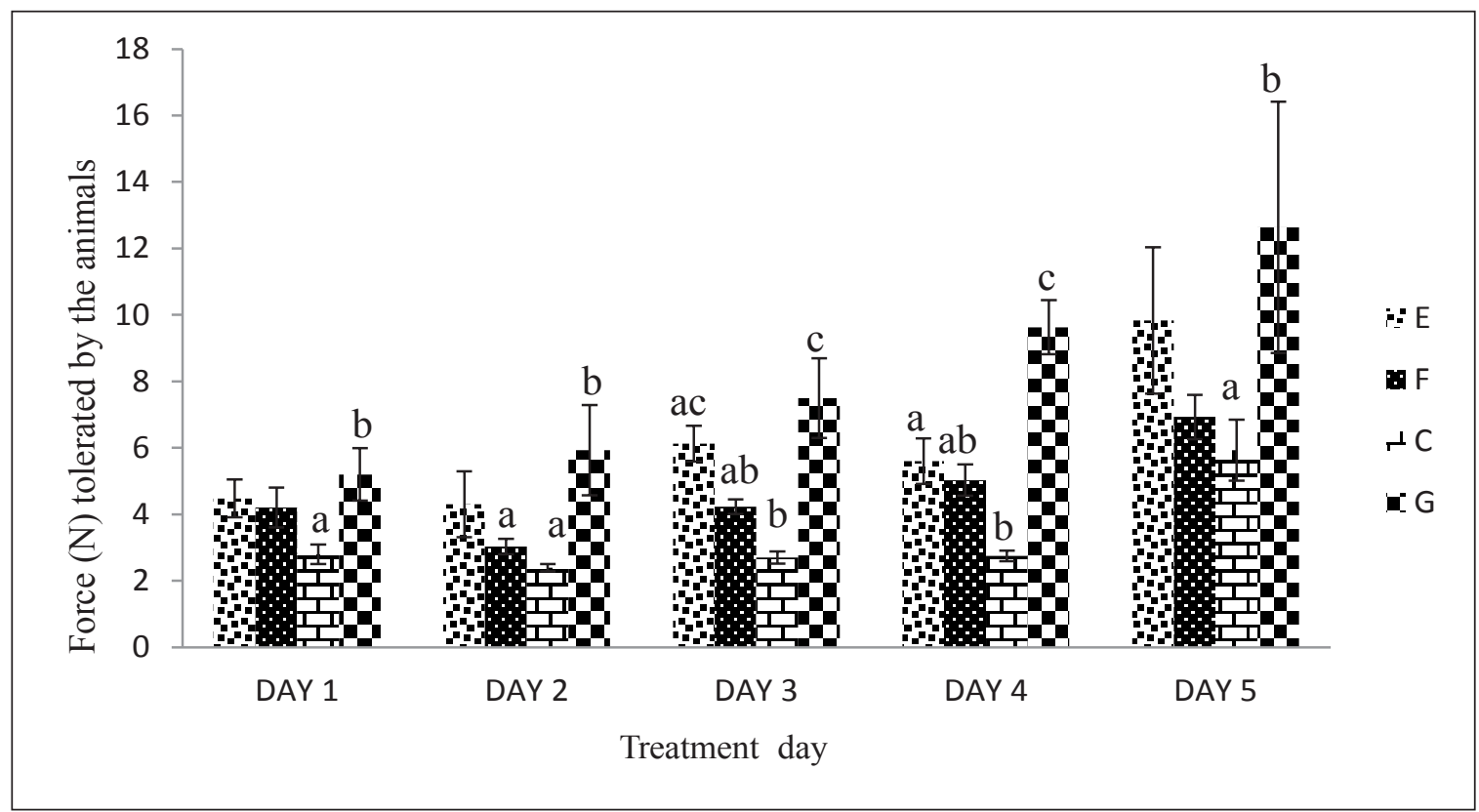

Fig. 3. Mean value of maximum force $(N)$ tolerated by the animals at different wound sites in the morning (n=4). KEY: E (Sansevieria longiflora sap); F (Sansevieria longiflora water extract); C (Physiological normal saline) and G (Xylocaine cream)

${ }^{a b c}$ Means in the same row with different superscript alphabets were significantly different $(\mathrm{p}<0.05)$

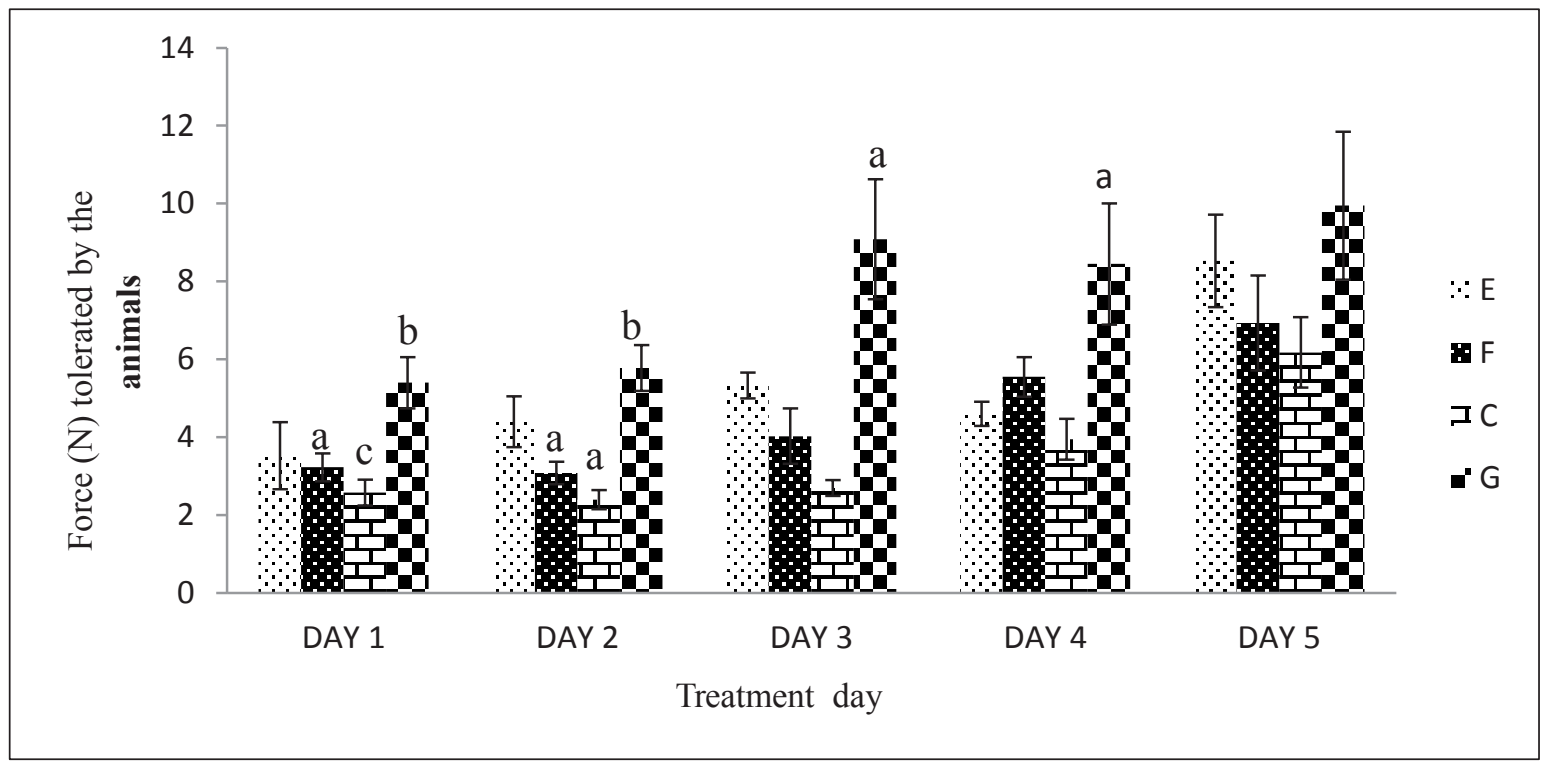

Fig. 4. Mean value of maximum force $(N)$ tolerated by the animals at different wound sites in the evening (n=4). KEY: E (Sansevieria longiflora sap); F (Sansevieria longiflora water extract); C (Physiological normal saline) and $G$ (Xylocaine cream)

${ }^{\mathrm{abc}}$ Means in the same row with different superscript alphabets were significantly different $(\mathrm{p}<0.05)$ 
$(2.58 \pm 0.33)$ and $S$. longiflora water extract $(3.23 \pm 0.36)$ and not different from that of $S$. longiflora sap $(3.53 \pm 0.86)$. This was similarly observed in the morning and evening of day 2 post incision. Whereas, on the day 3 and 4 post incision, the force tolerated by the xylocaine treated wounds was significantly higher than all other treatment groups, while on the morning of day 5 post incision, the force tolerated by the xylocaine treated wounds were significantly higher than that of PSS treated wounds and not different from that of S. longiflora sap and water extract. This showed that $S$. longiflora sap and water extract possess analgesic effect on incisional wounds however, the sap was more potent and effective than the water extract supporting the traditional methods of preparation. There is likelihood that some active ingredients were lost during the extraction.

This study has shown that $S$. longiflora possess some analgesic properties using the force gauge machine on experimental cutaneous wounds which was due to the flavonoids component of the secondary metabolites as described by Akpalo et al. (2015), Fakhim et al. (2015) and Christian et al. (2016). Flavonoids are free radical scavengers due to their high reactivity as hydrogen or electron donors. This explained their therapeutic potentials (Soobrattee et al., 2005). Inflammatory condition is associated with pain. The development of inflammation is initiated by the release of mediators of different structures/classes including serotonin, histamine, cytokines and chemokines, nitric oxide (NO), reactive oxygen species (ROS), and lipid mediators, such as prostanoids, leukotrienes, and lipoxins (Verri Jr. et al., 2012). Those derived from components present in the plasma include bradykinin and members of the complement and coagulation system (Robbins et al., 2010). Flavonoids interfere with these molecules at various degrees, depending on the concentration/doses of flavonoids used in vitro and in vivo (Verri Jr. et al., 2012). Studies have shown that flavonoids induce analgesic effects by inhibition of both inflammatory and neuropathic pain through mechanisms involving the inhibition of cytokine production (e.g., IL-1 $\beta$ ), prostaglandin, nitric oxide production and via endogenous opioid dependent mechanisms (Verri Jr. et al., 2012).

Flavonoids also inhibit the peroxidase active site of COX-1, COX-2, and 5 lipoxygenase (5-LO) (Burnett et al., 2007), resulting in inhibition of prostanoids (prostaglandins and tromboxanes) and leukotrienes production, respectively. Morikawa et al. (2003) similarly reported that flavonoids inhibited the COX-2 peroxidase active site (Burnett et al., 2007) as well as the nuclear factor kB (NF-kB) -dependent expression of COX-2. Inhibition of prostaglandins produced algesia as prostaglandins contributed to edema as a consequence of increased vascular permeability and modulated the activity of neurons responsible for painful stimuli perception and thermal regulation (Robbins et al., 2010). However, COX-1 inhibitors were known for their increase in incidence of gastric and intestinal ulcerations while COX-2 inhibitors increased the risk of cardiovascular problems (Buerkle et al., 2004). Since the activity of flavonoids do not rely exclusively on the inhibition of COX enzymes but affect other pathways concomitantly to COX inhibition, they do not present these common side effects of NSAIDs that target COX enzymes (Verri Jr. et al., 2012). In fact, flavonoids have opposite effects compared to the COX inhibitors. Hence, treatment with extracts containing flavonoids and/or flavonoid-rich fractions of extracts reduced the gastric lesions induced by NSAIDs, such as aspirin and indomethacin, or even promoted tissue healing (Alam et al., 2010; Vasconcelos et al., 2010).

Anbu et al. (2009) reported dose-dependent analgesic effects of ethanol and water extracts of Sansevieria trifasciata leaves. Jimuty et al. (2012) similarly reported the analgesic, cytotoxic and antioxidant activity of the whole plant part of $S$. roxburghiana. Other studies on Sansevieria species have documented its anti inflammatory activity (Da Silva et al., 2003) and analgesic property (Sunilson et al., 2009).

\section{Conclusion}

This study has revealed that $S$. longiflora sap and water extract has analgesic effects on incisional wounds which was due to the flavonoids contents of the secondary metabolite. This explains the use of this plant by the traditional medicine practitioner in Nigeria for different ailment relating to alleviation of pain. This study will serve as a preliminary study on this plant towards searching for potent analgesics for post procedural pain management.

\section{Acknowledgment}

We acknowledge the effort of Mr. Mustapha and Mr. Kabir, Department of Pharmacognosis, Faculty of Pharmacy, Ahmadu Bello University Zaria. The kind provision of the Digital algometer by Dr I. Misali and Dr E.O. Abidoye was also acknowledged. This research work was self financed as a part of a thesis.

\section{References}

Adeyemi OO, Akindele AJ and Ogunleye EA (2009), Evaluation of the antidiarrhoeal effect of Sansevieria liberica Gerome and Labroy (Agavaceae) root extract, Journal of Ethnopharmacology 123(3): 459-463. DOI: 10.1016/ j.jep.2009.03.023. 
Akpalo E, Tete-Benissan A, Awaga K and Akpagana K (2015), Review of twelve West Africa Medicinal Plants: Active phytochemical combinations in direct biochemically wound healing process, Journal of Medicinal Plant Research 9(34): 908-917.

Alam MS, Alam MA, Ahmad S, Najmi AK, Asif M and Jahangir T (2010), Protective effects of Punica granatum in experimentally-induced gastric ulcers, Toxicology Mechanism and Methods 20: 572-578

Aliero AA, Jimoh FO and Afolayan AJ (2008), Antioxidant and antibacterial properties of Sansevieria hyacinthoides, International Journal of Pure and Applied Sciences 2(3): 103-110.

Anbu JSJ, Jayaraj P, Varatharajan R, Thomas J, Jisha J and Muthappan M (2009), Analgesic and Antipyretic Effects of Sansevieria trifasciata Leaves, African Journal of Traditional, Complementary and Alternative Medicines 6(4): 529-533.

Buerkle MA, Lehrer S, Sohn HY, Conzen P, Pohl U and Kro“tz F (2004), Platelets in Thrombotic and Non-Thrombotic Disorders: Pathophysiology, Circulation 110: 2053-2059.

Bufalari A, Adami C, Angeli G and Short CE (2007), Pain assessment in animals, Veterinary Research Communications 31(1): 55-58.

Burnett BP, Jia, Q, Zhao Y and Levy RM (2007), A medicinal extract of Scutellaria baicalensis and Acacia catechu acts as a dual inhibitor of cyclooxygenase and 5-lipoxygenase to reduce inflammation, Journal of Medicinal Food 10(3): 442-451.

Christian A, Bekoe EO, Boakye YD, Dapaah SO, Appiah T and Bekoe SO (2016), Medicinal Plants and Natural Products with Demonstrated Wound Healing Properties In: Wound Healing - New insights into Ancient Challenges, INTECH P483-531. Downloaded from: http://www.intechopen.com/books/wound-healing-new-insightsinto- ancient-challenges.

Coetzee JF (2011), A review of pain assessment techniques and pharmacological approaches to pain relief after bovine castration: practical implications for cattle production within the United States, Applied Animal Behaviour Science 135: 192-213.

Crandell DE, Mathews KA and Dyson DH (2004), Effect of meloxicam and carprofen on renal function when administered to healthy dogs prior to anesthesia and painful stimulation, American Journal of Veterinary Research 65(10): 1384-90.
Da Silva AA, Da Silva BP, Parente JP and Valente AP (2003), A new bioactive steroidal saponin from Sansevieria cylindrical, Phytotherapy Research 17: 179-182.

Dhama K, Latheef SK, Mani S, Abdu Samad H, Karthik K, Tiwar R, Khan RU, Alagawany M, Farag MR, Alam GM, Laudadio V and Tufarelli V (2015), Multiple Beneficial Applications and Mode of Actions of Herbs in Poultry Health and Production- A Review, International Journal of Pharmacology 11(3): 152-176.

Evans WC and Trease GE (1996), Trease and Evan Pharmacognosy, $14^{\text {th }}$ Ed., W. B. Sounders Co. Ltd, London, pp 542-578.

Fakhim SA, Babaei H, Nia AK and Ashrafi J (2015), Wound healing effect of topical grape seed extract (Vitis Vinifera) on rat palatal mucosa, International Journal of Current Research and Academic Review 3(6): 477-489.

Franco LG, Moreno JCD, Neto ART, Souza MC and da Silva LAF (2014), Tramadol effects on clinical variables and the mechanical nociceptive threshold in horses, Ciênc. Rural Santa Maria 44(3): 517-523.

Harborne JB (1973), Phytochemcial methods, Chapman and Hall Ltd., London, pp 49-188.

Jimuty R, Kuddus M, Begum B and Hasan C (2012), Evaluation of analgesic, cytotoxic and antioxidant activities of Sansevieria roxburghiana Schult. and Schult. f., Asian Pacific Journal of Tropical Biomedicine S723-S726.

Lascelles BD, Blikslager AT, Fox SM and Reece D (2005), Gastrointestinal tract perforation in dogs treated with a selective cyclooxygenase-2 inhibitor: 29 cases (2002-2003), Journal of American Veterinary Medical Association 227(7): 1112-1117.

Mark E, Ilona R, Gregg G, Jamie K, Michael P, Sheilah R and Wendy S (2015), AAHA/AAFP Pain Management Guidelines for Dogs and Cats, Veterinary Practice Guidelines, American Animal Hospital Association, Journal of the America Animal Hospital Association, 51(2): 67-84.

Mathews K, Kronen PW, Lascelles D, Nolan A, Robertson S, Steagall PVM and Yamashita K (2014), Guidelines for Recognition, Assessment and Treatment of Pain: WSAVA Global Pain Council, Journal of Small Animal Practice 55(6): 10-68. DOI: 10.1111/jsap.12200.

Mimaki Y, Inoue T, Kuroda M and Sashida Y (1996), Steroidal saponins from Sansevieria trifisciata, Journal of Phytochemistry 43: 1325-1331. 
Molony V and Kent J (1997), Assessment of acute pain in farm animals using behavioral and physiological measurements. Journal of animal science 75(1): $266-272$.

Morikawa K, Nonaka M, Narahara M, Torii I, Kawaguchi K, Yoshikawa T, Kumazawa Y and Morikawa S (2003), Inhibitory effect of quercetin on carrageenan-induced inflammation in rats, Life Science 74(6): 709-721.

Nweze ET, Okafor JI and Njoku O (2004), Antimicrobial Activities of Methanolic extract of Trema guineesis (Schumm and Thorn) and Morinda lucinda Benth used in Nigerian Herb. Medicinal Practice, Journal of Biological Research and Biotechnology 2(1): 34-46. DOI: $10.4314 /$ br.v2i1.28540.

Ochi H, Hara Y, Asou Y, Harada Y, Nezu Y, Yogo T, Shinomiya $\mathrm{K}$ and Tagawa M (2011), Effects of long-term administration of carprofen on healing of a tibial osteotomy in dogs, American Journal of Veterinary Research 72(5): 634-41.

Ogukwe CE, Oguzie EE, Unaegbu C, Unaegbu C and Okolue BN (2004), Phytochemical Screening on the leaves of Sansevieria trifasciata, Journal of Chemical Society of Nigeria 29: 8-9.

Olivia C (2005), An assessment of medicinal hemp plant extracts as natural antibiotic and immune modulation phytotherapies, M.Sc Thesis, Faculty of Natural Sciences, University of the Western Cape.

Osabohien E and Egboh SHO (2008), Utilization of Bowstring Hemp Fiber as a Filler in Natural Rubber Compounds, Journal of Applied Polymer Science 107: 210-214.

Philip DPK, Valivittan KK and Kumar CPG (2011), Phytochemical Screening and Antimicrobial Activity of Sansevieria roxburghiana. Schult. and Schult. F, Middle-East Journal of Scientific Research 10(4): 512-518.

Pramoda KJ and Hanumanth KG (2015), Phytochemical analysis of secondary metabolites and antimicrobial activity of Sansevieria roxburghiana, World Journal of Pharmaceutical Research 4(2): 1072-1077.

Prashanthi R, Mohan N and Siva GV (2012), Wound healing property of aqueous extract of seed and outer layer of Momordica charantia L. on albino rats, Indian Journal of Science and Technology 5(1): 1936- 1940.
Robbins SL, Kumar V, Abbas AK, Cotran RS, Fausto NR and Cotran R (2010), Pathologic basis of disease, Saunders/Elsevier, Philadelphia, pp 43-78.

Rocca GD, Catanzaro A, Di Salvo A and Goldberg ME (2015), Diagnosis of Pain in Small Companion Animals, American Journal of Animal and Veterinary Sciences 10(2): 57-66. DOI: 10.3844/ajavsp.2015.57.66.

Sofowara A (1993), Medicinal plants and Traditional medicine in Africa, Spectrum Books Ltd, Ibadan, Nigeria, p 289.

Soobrattee MA, Neergheen VS, Luximon-Ramma A, Aruoma OI and Bahorun T (2005), Phenolics as potential antioxidant therapeutic agents: mechanism and actions, Mutation Research 579(1-2): 200-213.

Sunilson J, Jayaraj P and Varatharajan (2009), Analgesic and Antipyretic Effects of Sansevieria trifasciata Leaves, African Journal of Traditional, Complementary and Alternative medicines 6(4): 529-533.

Vasconcelos PC, Andreo MA, Vilegas W, Hiruma-Lima CA and Pellizzon CH (2010), Effect of Mouriri pusa tannins and flavonoids on prevention and treatment against experimental gastric ulcer, Journal of Ethnopharmacology 131(1): 146-153.

Verri Jr WA, Vicentini FTM, Baracat MM, Georgetti SR, Cardoso RDR, Cunha TM, Ferreira SH, Cunha FQ, Fonseca MJV and Casagrande R (2012), Flavonoids as Anti-Inflammatory and Analgesic Drugs: Mechanisms of Action and Perspectives in the Development of Pharmaceutical Forms, Bioactive Natural Products 36: 297-330. DOI: 10.1016/B978-0- 444- 538369.00026-8.

Wasciky R and Hoehn W (1951), The crude saponin content of some Brazilian plants, Anais da Faculdade de Farmacia e Odontologia 9: 17-26.

Woolf CJ (2010), What is this thing called pain?, Journal of Clinical Investigation 120(11): 3742-3744. 